
JEA
Jurnal Eksplorasi Akuntansi
Vol. 2, No 1, Seri E, Februari 2020, Hal 2479-2493
ISSN : 2656-3649 (Online)
http://jea.ppj.unp.ac.id/index.php/jea/issue/view/21

\title{
Pengaruh Kualitas Sumber Daya Manusia, Implementasi Sistem Informasi Manajemen Daerah Dan Penerapan Standar Akuntansi Pemerintah Terhadap Kualitas Laporan Keuangan Pemerintah Daerah (Studi Empiris Pada OPD Provinsi Sumatera Barat)
}

\author{
Meisy Hendri' ${ }^{1}$, Erinos NR ${ }^{2}$ \\ ${ }^{1}$ Alumni Jurusan Akuntansi Fakultas Ekonomi, Universitas Negeri Padang \\ ${ }^{2}$ Jurusan Akuntansi Fakultas Ekonomi, Universitas Negeri Padang \\ *Korespondensi: meisyhendri10@gmail.com
}

\begin{abstract}
This study aims to empirically pirove the influence of the quality of human resources, the implementation of regional management information systems (SIMDA) and the application of government accounting standards to the quality of local government financial reports. This research is causative research. The population in this study was 39 Regional Organizations (OPD) of West Sumatra Province. The sample in this study used the Total Sampling method. The type of data used in this study is primary data. Data collection techniques using a questionnaire consisting of 3 respondents in each OPD so that the questionnaire distributed was 117 questionaires. The analytical method used is Multiple Regression Analysis using SPSS version 20.00. The results showed: the quality of human resources, implementation of regional management information systems and the application of government accounting standards have a positive effect on the quality of local government financial reports.
\end{abstract}

Keywords: Quality of Human Resources; Implementation of Regional Management Information Systems (SIMDA); Application of government Accounting Standards

How to cite (APA ${ }^{\text {th }}$ style):

Hendri, Meisy \& NR, Erinos (2020). Pengaruh Kuaitas Sumber Daya Manusia, Implementasi Sistem Informasi Manajemen Daerah dan Penerapan Standar Akuntansi Pemerintah terhadap Kualitas Laporan Keuangan Pemerintah Daerah. Jurnal Eksplorasi Akuntansi, 2(1), Seri E, 2479-2493.

\section{PENDAHULUAN}

Pemerintah sebaiknya bertanggungjawab dalam membuat laporan keuangan sebagai alat pengendalian kerja, evaluasi kerja, pertanggungjawaban kerja dan pengambilan keputusan dalam bekerja. Pemerintah perlu sekali membuat laporan keuangan yang berkualitas, supaya pemakai laporan keuangan dapat memahami informasi yang terdapat dalam laporan keuanhgan tersebut. Laporan keuangan pemerintah yang tidak baik akan menimbulkan implikasi yang tidak baik, contohnya saja dapat menurunkan kepercayaan masyarakat dalam pengelolaan dana publik dan kualitas keputusan akan menjadi negatif (Alfiani, 2017). 
Kualitas adalah kesesuaian berbasisis dengan standar dan diukur berbasis kadar ketidaksesuaiannya serta dapat dilakukan melalui pemeriksaan suatu laporan keuangan merupakan hasil akhir dari proses akuntansi yang dilakukan seperti swasta, publik dituntut untuk bisa membuat laporan keuangan secara formal seperti laporan realisasi anggaran, operasional, saldo anggaran lebih, neraca, arus kas, perubahan ekuitas, dan CALK, Laporan keuangan yang disusun harus memenuhi prinsip-prinsip yang dinyatakan jelas dalam Peraturan Pemerintah Nomor 71 tahun 2010 yang dimana harus mencakup empat karakteristik yaitu rellevan, andal, dapat dibandiingkan, dan dapat dipahami.

Informasi yang dibutuhkan oleh institusi publik atas pelaporan keuangan pemerintah daerah adalah informasi kepatuhan terhadap aturan, informasi kinerja, informasi kondisi keuangan dan informasi perencanaan dan penganggaran. Tidak hanya itu, laporan keuangan pemerintah daerah juga harus berkualitas yakni relevan, andal, dapat dibandingkan, serta dapat di pahami oleh penggunanya. Pengungkapan informasi dalam laporan keuangan memiliki dampak ekonomis dan subtansial dalam pengambilan keputusan. Dalam pelaporan keuangan pemerintah daerah, baik pihak eksekutif maupun legislatif sama-sama berkepentingan untuk memastikan bahwa laporan keuangan pemerintah daerah telah memberikan penjelasan yang memadai mengenai kepatuhan terhadap aturan, informasi kinerja, informasi kondisi keuangan, serta informasi perencanaan dan penganggaran (Novia et.al, 2015).

Sayangnya sejumlah publikasi riset menunjukan bahwa sebagian besar pemerintah daerah masih enggan untuk memanfaatkan website resmi pemda untuk memberikan informasi pengelolaan anggaran dan keuangan daerah kepada publik. Misalnya penelitian Agustin (2014) menemukan bahwa belum seluruh pemkab/pemkot di propinsi Sumatera Barat memanfaatkan menu transparansi pengelolaan anggaran (TPA) dalam website resmi pemerinta daerah untuk mempublikasikan secara lengkap dan konsisten jenis dokumen-dokumen terkait dengan penggunaan anggaran. Meskipun sebagian besar website Kabupaten di Sumatera Barat telah terdapat menu khusus/link bernama TPA (transparansi pengelolaan anggaran) untuk mendownload informasi atau dokumen keuangan dan kinerja tetapi menu khusus dan link tersebut terkadang kosong, tidak memuat secara lengkap, dan tidak dipublikasikan secara konsisten setiap tahunnya,

Sejumlah riset terdahulu telah mencoba mengidentifikasi factor-faktor yang mempengaruhi kualitas laporan keuangan. Hal ini penting mengingat riset Agustin dan Arza (2019) menemukan anomali antara akuntabilitas dan transparansi publik terkait dengan manajemen pengelolaan keuangan daerah. Akuntabilitas publik telah meningkat dalam 7 tahun terakhir (2012-2019), dimana seluruh pemerintah kabupaten/kota di propinsi Sumatera Barat mempublikasikan pada website resmi maupun media massa setiap opini WTP dari BPK atas LKPD. Namun perilaku serupa tidak terjadi dalam konteks transparansi publik, dimana hampir setengah dari 19 pemerintah kabupaten/kota di propinsi Sumatera Barat yang bersedia mengungkapkan secara terbatas dokumen-dokumen terkait pengelolaan anggaran daerah (hanya 5-7 dokumen dari total 12 dokumen). Riset Halmawati dan Nova (2014) pada SKPD di Kabupaten Sijunjung menemukan bahwa Peran internal audit berpengaruh positif terhadap kualitas laporan keuangan pemerintah daerah. Namun di sisi lain, komitmen karyawan serta pemahaman akuntansi justru tidak berpengaruh terhadap kualitas laporan keuangan. Faktor berikutnya yang mempengaruhi kualitas laporan keuangan Pemerintah Daerah yaitu Sumber Daya Manusia (Indriasari, 2008; Dewi, 2015; dan Gumelar, 2017). Emilda (2014) mengatakan bahwa SDM merupakan kunci atau patokan dari keberhasilan sebuah sesuatu perusahan, suatu peurasahaan memiliki nilai yang baik disebabkan oleh kemampuan, pengetahuann, dan 
keterampilan. SDM yang berkualitas merupakan salah satu faktor yang sangat penting dalam suatu perusahaan untuk menghasilkan laporan keuangan yang baik.

Hasil penelitian terdahulu menunjukkan bahwa SDM memiliki pengaruh signifikan terhadap kualitas laporan keuangan oleh Indriasari (2008) yang menemukan bahwa bukti empiris bahwasanya kualitas SDM dikota Palembang dan Ogan Ilir tidak berpengaruh signifikan terhadap keteranndalan laporan keuagan Pemerintah Daerah. Penelitian ini berbeda dengan penelitian yang dilakukan oleh Dewi (2015) sejalan dengan penelitian Gumelar (2017).

Faktor berikutnya yang mempengaruhi kualitas laporan keuangan adalah faktor Impelementasi Sistem Informasi Manajemen Daerah (Abidin, 2018; Waskito, 2014; Ulfiati, 2017; dan Alfian, 2015). Untuk mewujudkan sebuah pengelolaan keuangan daerah yang cepat, aman, tepat, dan akurat, pemerintah daerah memderlukan sebuah sistem apllikasi dalam pembuatan laporan keuangan, dan aplikasi ini sangat besar pengaruhnya terhadap kualitas laporan keuangan daerah yaitu Sistem Informasi Manajemen Keuanganh Daerah (SIMDA) sebuah sistem berbasis dengan aplikasi teknologi yang telah dikembangkan untuk mendukung tercapainya sebuah akuntabilitas bagi Pemerintah Daerah baik ditingkat pelaporan (SKPKD) ataupun ditingkat akuntansi (SKPD) (Alfiani, 2017).

Hasil penelitian terdahulu menunjukkan bahwa Implementasi Sistem Informasi Manajemen Daerah berpengaruh terhadap kualitas laporan keuangan pemerintah dilakukan oleh Abidin (2018) menjelaskan bagaimana Implementasi SIMDA berpengaruh sangat positif terhadap bagaimana kualitas dari laporan keuangan daerah, artinya apabila pengaruh Implementasi SIMDA semakin membaik maka kualitas laporan keuangan tersebut akan semakin meningkat dan baik, hal ini senada dengan penelitian Waskito (2014), dan Ulfiati (2017). Berbeda dengan penelitian yang dilakukan oleh Alfian (2015). Rendahnya kualitas laporan keuangan Pemerintah Daerah juga dipengaruhi oleh faktor penyusunan laporan keuangan yang belum sesuai dengan Standar Akuntansi Pemerintahan Pemerintah (Nugraheni, 2008; Kusumah, 2012; Sako, 2018; dan Fikri, 2016). Menurut Zeyn (2011) dalam Adhi (2017).

Hasil penelitian terdahulu menunjukkan bahwa penerapan SAP berpengaruh terhadap kualitas laporan keuangan pemerintah dilakukan oleh dilakukan Nugraheni (2008) melihat bahwa penerapan SAP tersebut berpengaruh signifikan terhadap kualitas laporan keuangan. Begitu juga dengan pienelitian yang dilakukan oleh Kusumah (2012) menunjukkan bahwa hasil penelitiain penerapan SAP berpengaruh positif terhadap kualitas laporan keuangan, sejalan dengan penelitian yang dilakukan oleh Sako (2018) berbeda dengan Fikri (2016) dalam penelitianya menemukan bahwa Penerapan Standar Akuntansi Pemerintah tidak berpengaruh signifikan terhadap Kualitas Laporan Keuangan.

Banyaknya kasus tentang kualitas laporan keuangan Pemerintah Daerah di Indonesia masih menjadi isu atau berita hangat yang perlu dikaji lebih dalam lagi. Dibuktikan saja dengan masih minimnya Pemerintah Daerah yang mendapatkan opini Wajar Tanpa Pengecualian (WTP) dari hasil audit yang dilakukan oleh Badan Pemeriksa Keuangan (BPK) masihi relatif sedikit. Hal ini dapat dilihat dari hasil pemeriksaan yang dikeluarkan oleh BPK RI September 2017 adanya Operasi Tangkap Tangan (OTT) oleh Komisi Pemberantasan Korupsi (KPK) terhadap dua auditor BPK. Melihat berbagai tanggapan dari sejumlah pihak di Sumbar, termasuk mempertanyakan opini WTP yang baru saja diterima oleh Pemprov Sumhbar.

Operasi Tangkap Tangan (OTT) itu terkait dengan pemberian predikat Wajar Tanpa Pengecualian (WTP) pada Kementerian Desa, Pembangunan Daerah Tertinggal dan Transmigrasi (Kemendes PDTT). Sumbar juga mendapatkan WTP di tengah adanya dugaan penyimpangan 30 item dalam Laporan Keuangan Pemerintah Daerah (LKPD) 2016 dengan 
temuan mencapai Rp 45 minliar. Pakar Hukum Tata Negara dari Universitash Andalas, Feri Amsari menilai WTP yang diperoleh Pemprov Sumbar sekarang ini patut dicurigai. Kecurigaan terhadap WTP yang didapatkan Pemprov Sumbar tersebut, diduga sekitar Rp 45 miliar dana menyimpang dari 30 item temuan pada LPKD. Menurut Feri penyimpangan dana Rp 45 miliar tersebut harus diusut karena hal tersebut merupakan indikasi yang salah dengan status WTP yang diterima Pemprov Sumbar. (www.harianhaluan.com).

Berdasarkan hasil penelitian sebelumnya yang masih belum konsisten memotivasi peneliti untuk meneliti kembali mengenai kualitas laporan keuangan pemerintah pada intansi pemerintah. Peneliti melakukan penelitian ini juga untuk mengetahui sejauh mana kualitas laporan keuangan yang di hasilkan oleh Organisasi Pemeritah Daerah Sumbar. Maka dari itu saya penulis tertarik melakukan penelitian berjudul "Pengaruh Kualitas Sumber Daya Manusia, Impelementasi Sistem Manajemen Daerah (SIMDA), dan Peneraipan Standar Akuntansi Pemerintah terhadap Kualiitas Laporan Keuangan Pemerintah Daerah (Studi Empiris pada Organisai Pemerintah Daerah Provinsi Sumatera Barat)".

\section{REVIU LITERATUR DAN PENGEMBANGAN HIPOTESIS Stewardship Theory}

Grand theory yang mendasari penelitian ini merupakan bagian dari agency theory yaitu stewardship theory. Donaldson dan Davis (1991) dalam Anton (2010) Stewardship menggambarkan bagaimana bentuk bahwasanya tidak adaa situasi manajemen tergesa-gesa dalam tujuan-tujuan individu melainkan untuk kepentingan bersama. Tercapainya kesuksesan dalam sebuah organisasi pemerintah itu bisa ditingkatkan dengan maksimalisasikan utilitais principals dan manajemen. Awal berkembangannya akuntainsi organisasi disektor publik untuk memenuhi kebutuhan informasi antaralain stewards dengan principals. Akuntansi sebagai penggerak serta diikuti berbagai perubahaman yang semakin komplleks, adanya spesialissi dalam akuntansi juga ada perkembangannya dalam organisasi sektor publik, selaku principals sangat sulitatau payah melakukan sendiri fungsi-fungsi pengelolaan. (Haliah, 2012 dalam Wahida 2015).

Hubungan teori stewardship dsisini adalah menjelaskan bagaimana eksistensi pemerintah daerah sebagaimana lembaga atau wahana yang bisa dipercayai dalam mewadahi keluhan masyarakat, dan juga memberikan pelayanan yang baik terhadap masyarakat, dan mahmpu mempertanggunggjawabkan keuangan yang diamanahkan dan ekonomi terpenuhi serta kesejahteraan publik tersebut dapat tercapai secar maksimal, untuk melakksanakan pertanggungjawabtersebut maka stewards (manajer dan auditor internal) sangat perlu untuk mengatur semua kemampuannya dalam mengefektifkan pengendalian interenal agar dapat menghasislkan laporan informasi keuangan yang berkualitas (Wahida, 2015).

\section{Kualitas Laporan Keuangan Pemerintah Daerah a. Pengertian Laporan Keuangan}

Mardiasmo (2009) adalah kepatuhan dalam pengelolaan, akuntabilitas, pelaporannya, perencanaa, informasi, kelangsungan sebuah organisasinya, dan hubungan masyarakat. Laporan keuangan pemerintah yang sebaik menurut Peraturan Pemerintah Nomor 71 tahun 2010 harus mencakup empat karakteristik yaitu releva, andal, dapat diibandingkan, dan dapat dipahaminya. 


\section{b. Kualitas Laporan Keuangan}

Laporan keuanga di katakan berkualitas jika informasi yang disajikan harus disusun secara baik, benar dan sesuai dengan prinsip-prinsip akuntansi. Defitri (2016) kualitas laporan keuangan pemerintah daerahm merupakan kemampuannya informasi yang dapat dipahami dan memenuhi kebutuuhan pemakai didalam mengaambil keputusan.

\section{c. Kualitas Sumber Daya Manusia}

Sumber daya manusia merupakan terpenting dalam instansi dan berguna dalam meningkatkan SDM, dalam meningkatkan kualitas tersebut harus ada pembinaan sumber daya manusia bertujun agar tenaga kerja bisa disiplin. Widodo (2001) dalam Galuh (2012) menjelaskan sumber daya manusia merupakan kemampuan untuk melaksanakan tugas dan tanggung jawab yang diberiikan kepadanya dengan bekal penndidikan agar terciptanya hal yang positif.

\section{d. Implementasi Sistem Informasi Manajemen Daerah (SIMDA)}

Sistem informasi merupakan unsur yang berkaitan lalu digunakan untuk mengambil keputusan dengan sangat tepat sekali untuk sebagaimana dalam mancapai tujuan tertentu. Menurut Hall (2007) mengatakan suatu prosesis dan pemakai melakukan tindakan yang dapat dilakukan atau tidak dilakukan, dapat berkenan dengan akuuntansi. Sijstem informasi ini sangat besar efeknya terhadap kinerja invidu. Mengelola informasi sangat dibutuhkan, khususnya dalam pemerintahan, apabila informasi yang di lakukan dikerjakan dengan sebaiknya maka dapat meningkatkan kualitas laporan keuaangan pemerointah daerah.

\section{Penerapan Standar Akuntansi Pemerintah}

\section{a. Pengertian Standar Akuntansi Pemerintah}

Penerapan Standar Akuntansi Pemerintahan dapat diterapkan di pemerintahan, yaitu pusaat, daerah, dan satuannya organisasi dilingkungan pemerintahan pusat.

\section{b. Komponen Pernyataan Standar Akuntansi Pemerintah}

Berdasarkan Peraturan Pemerintah Nomor 71 Tahun 2010 tentang Standar Akuntansi Pemerintah berbasis kas menuju akrual memuat 12 lampiran yaitu:

1. Penyajian Laporan Keuangan

2. Laporan Realilasi Anggaran Berbasis Kas

3. Laporan Arus Kas

4. Catatan atas Laporan Keuangan

5. Akuntansi Persediaan

6. Akuntansi Investasi

7. Akuntansi Aset tetap

8. Akuntansi Konstruksi dalam pengerjaan.

9. Akuntansi Kewajiban

10. Koreksi Kesalahan

11. Laporan Keuangan Konsolidasian

12. Laporan Operasional 


\section{Hubungan Kualitas Sumber Daya Manusia dengan Kualitas Laporan Keuangan Pemerintah}

Kualitas laporan keuangan melihat sejauhmaana laporan tersebut yangdisajikan untuk melihat informasiyang baiik dan merupakan laporan yang berterstriuktur mengenai pelaporan posisi keuangan dan transaksi yang dilakukan dengan mempertanggungjawabkan suatu entitas laporan. Dalam pengelolaan keuangan daerah yang baik, tentunya harus memiliki sumber daya manusia yang berkualitas dan baik, baikpun dari segi keahlian, atau yang lainya. Penelitian terdahulu yang dilakukan oleh Abidin (2018) menyatakan bahwa yang kualitas sumber dayi manusia berpengaruh positif terhadap kualitasisasi laporan keuangan pemerintah daerah, sejalan dengan penelitian Gumelar (2017) dan Ulfiati (2017). Berbeda dengan Indriasari (2008.

H1: Kualitas Sumber Daya Manusia berpengaruh positif terhadap Kualitas Laporan Keuangan Pemerintah

\section{Hubungan Implementasi Sistem Informasi Manajemen Daerah dengan Kualitas Laporan Keuangan Pemerintah}

Grande (2011) Sisitem informasnsi akuntansi aplkasi teknologi informasi dan sistem yang dirancanng membantu untuk pengelolaan dan pengendalian topiok yang terkait dengan bidang ekonolmi keuangan perusahaan. Sejalan dengan penelitian Salehi (2010) Sistem informasi akuntansi akan meningkatkan kinerja individu dalam menghasilkan laporan yang berkualitas. Kualitas informasi yang terdapat dalam laporan keuangan dapat dievaluasikan dengan empat atribut akurasi, ftepat waktu waktu, kelengkapan, dan konsistensi. Ole (2014) aplikasi SIMDA keuangan dapat menghasilkan informasi yang labih baik dibandingkan data manual.

Hasil penelitian Tagela (2014) dan Mohamad (2014) menemukan bahwa aplikasi SIMDA berpengaruh positif. Penelitan terdahulu yang dilakukan oleh Abidin (2018) sistem informasi manajemen daerah berpengaruh positif, sejalan dengan penelitian Ulfiati (2017) dan Ole (2014). Berbeda dengan Alfian (2015).

H2: Implementasi Sistem Informasi Manajemen Daerah berpengaruh positif terhadap Kualitas Laporan Keuangan Pemerintah

\section{Hubungan Penerapan Standar Akuntansi Pemerintah dengan Kualitas Laporan Keuangan Pemerintah}

Penerapan Standar Akuntansi dapat memberikan pengaruh yang baik terhadap Kualitas Laporan Keuanga yang berhasil menciptakan sebuah laporan yang berkualitas, bermutu dan dmemberikan informasi lengkap. Nordiwan dalam Permana (2011) menyatakan dengani pengaruh antara Standar Akuntansi Pemerintah daerah diterapkan dilingkungan pemerintah, baik di pemerinthah pusat dan departemen maupun. Dari uraian disimpulkan bahwa penerapan SAP ini diyakini akain berdampak pada pemningkatan kualitas laporan keuangan pemerintah pusat.

Penelitin terdahulu yang dilakukan oleh Abidin (2018) menyatakan bahwa penerapan standar akuntansi pemerintah berpengaruh positif terhadap kualitas laporan keuangan pemerintah, sejalan dengan penelitian Adhi (2013), Ulfiati (2017) dan Gumelar (2017). Berbeda dengan penelitian yang dilakukan oleh Fikri (2016).

H3: Penerapan Standar Akuntansi Pemerintah berpengaruh positif terhadap Kualitas Laporan Keuangan Pemerintah 


\section{KERANGKA KONSEPTUAL}

Untuk memudahkan memahami faktor-faktor yang mempengaruhi penyerapan anggaran belanja maka penulis menyusun kerangka konseptual sebagai berikut:

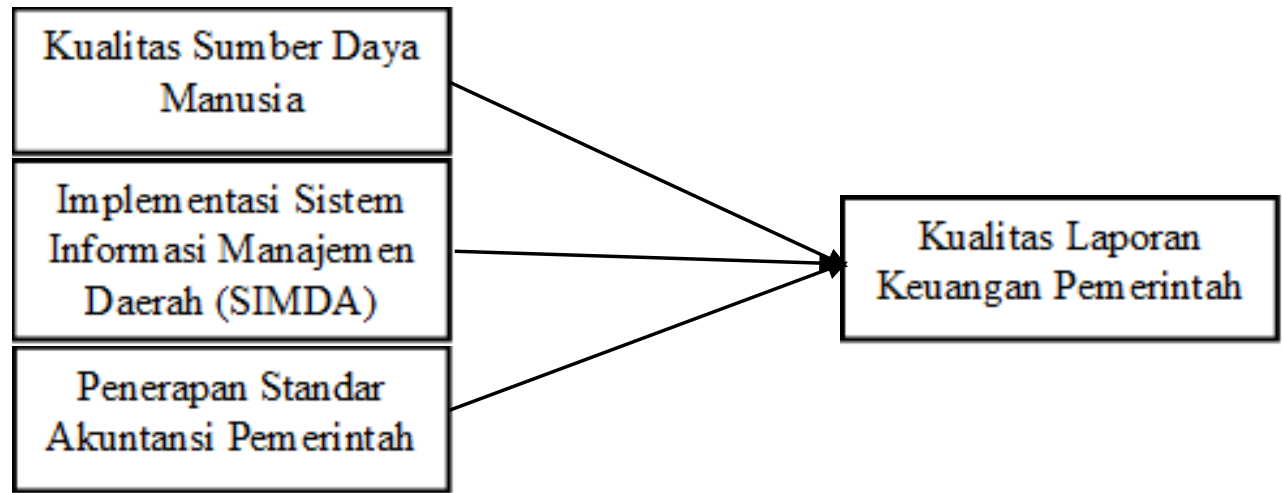

\section{Gambar 1 \\ Kerangka Konseptual}

\section{METODE PENELITIAN}

\section{Jenis Penelitian}

Jenis penelitian ini tergolong penelitian kausalitas, penelitian kausalitas bertujuan untuk mengetahu bagaimani hubungan serta pengaruh variabel independen terhadap variabel dependen.

\section{Populasi dan Sampel}

Populasi adalah semua elemen yang dapat digunakan dengan membuat kesimpulan. Populasi pada penelitian ini adalah 39 OPD Provinsi Sumatera Barat. Berdasarkan data yang diperoleh dari Dinas Pengelolaan Keuangan Daerah Provinsi Sumatera Barat yang terdiri dari Dinas, Badan, Sekretariat dan Inspektorat. Pengambilan sampel dalam penelitian ini dilakukan dengan teknik purposive sampling yaitu pemilihan sampel berdasarkan kriteria tertentu.

\section{Jenis dan Teknik Pengumpulan Data}

Jenis data digunakan primer. Teknik pengumpulan data menggunakan kuesioner berupa suatu pernyataan yang diberikan kepada responden untuk diisi berdasarkan pendoapat masing-masing. Dari data responden diatas, maka peneliti akkan mengajukan 3 buah kuesioner kepada 39 OPD Provinsi Sumatera Barat. Sehingga total kuesioner yang akan disebarkan adalah sejumlah 117 kuesioner.

\section{HASIL DAN PEMBAHASAN}

Tabel 1. Descriptive Statistics

\begin{tabular}{|l|c|c|c|c|c|}
\hline \multicolumn{7}{|c|}{ Descriptive Statistics } \\
\hline & $\mathrm{N}$ & Minimum & Maximum & Mean & Std. Deviation \\
\hline $\mathrm{Y}$ & 102 & 29 & 55 & 44.54 & 6.042 \\
\hline $\mathrm{x} 1$ & 102 & 21 & 45 & 33.27 & 4.187 \\
\hline $\mathrm{x} 2$ & 102 & 10 & 27 & 23.07 & 2.163 \\
\hline $\mathrm{x} 3$ & 102 & 25 & 70 & 54.75 & 7.585 \\
\hline \multicolumn{1}{|c|}{ Valid N (listwise) } & 102 & & & & \\
\hline
\end{tabular}


Tabel di atas, dapat dilihat bahwa nilai rata-rata (mean) kualitas laporan keuangan pemerintah sebagai variabel dependen sebesar 44.54 dengan standar deviasi sebesar 6.042. Nilai maksimum dan minimum kualitas laporan keuangan pemerintah adalah 55 dan 29. Variabel independen pertama dalam penelitian ini adalah kualitas sumber daya manusia memiliki nilai rata-rata sebesar 33.27 dengan standar deviasi 4.187. Nilai maksimum dan minimum pada ini variabel kualitas sumber daya manusia adalah 45 dan 21. Variabel independen yang kedua adalah implementasi sistem informasi manajemen daerah memiliki nilai rata-rata sebesar 23.07 dengan standar deviasi 2.163. Nilai maksimum dan minimum variabel implementasi sistem informasi manajemen daerah adalah sebesar 27 dan 10. Selanjutnya variabel independen yang ketiga adalah penerapan standar akuntansi pemerintah memiliki nilai rata-rata sebesar 54.75 dan standar deviasi 7.585. Nilai maksimum dan minimum variabel penerapan standar akuantansi pemerintah adalah sebesar 70 dan 25. Hal ini menunjukkan bahwa data dalam penelitian ini beragam dan bervariasi dikarenakan standar deviasi yang dimiliki oleh semua variabel besar dari 0 .

Tabel 2. Uji F

\begin{tabular}{|c|c|c|c|c|c|c|}
\hline \multicolumn{7}{|c|}{ ANOVA $^{\mathrm{a}}$} \\
\hline \multicolumn{2}{|c|}{ Model } & Sum of Squares & df & Mean Square & F & Sig. \\
\cline { 2 - 7 } & Regression & 885.321 & 3 & 295.107 & 10.255 & $.000^{\mathrm{b}}$ \\
\cline { 2 - 7 } & Residual & 2820.090 & 98 & 28.776 & & \\
\cline { 2 - 7 } & Total & 3705.412 & 101 & & & \\
\hline \multicolumn{2}{|l}{ a. Dependent Variable: total_y } \\
b. Predictors: (Constant), total_x3, total_x2, total_x1 \\
\hline
\end{tabular}

Hasil uji pada tabel diperoleh nilai $\mathrm{F}=10,225$ dengan nilai signifikansi sebesar $\mathrm{P}$ value $=$ 0,000 yang lebih kecil dari $\alpha=0,05$. Jadi dapat disimpulkan bahwa model penelitian yang digunakan dianggap layak uji dan ketiga variabel mampu menjelaskan kinerja manajerial pada OPD Provinsi Sumatera Barat.

Tabel 3. Uji Adjusted R2

\begin{tabular}{|c|c|c|c|c|}
\hline \multicolumn{5}{|c|}{ Model Summary $^{\mathrm{b}}$} \\
\hline Model & $\mathrm{R}$ & $\mathrm{R}$ Square & Adjusted R Square & Std. Error of the Estimate \\
\hline 1 & $.489^{\mathrm{a}}$ & .239 & .216 & 5.36437 \\
\hline \multicolumn{6}{|c|}{ a. Predictors: (Constant), total_x3, total_x2, total_x1 } \\
\hline \multicolumn{6}{|c|}{ b. Dependent Variable: total_y } \\
\hline
\end{tabular}

Dari tampilan output SPSS model summary pada tabel di atas besarnya Adjusted R Square adalah 0,216 Hal ini mengindikasi bahwa kontribusi variabel kualitas sumber daya manusia, implementasi sistem informasi manajemen daerah dan penerapan standar akuntansi pemerintah sebesar $21,6 \%$, sedangkan sisanya sebesar 78,4\% di tentukan oleh faktor lain di luar model yang tidak terdeteksi dalam penelitian ini. 
Tabel 3. Analisis Model Persamaan

\begin{tabular}{|c|c|c|c|c|c|c|}
\hline \multicolumn{7}{|c|}{ Coefficients $^{\mathrm{a}}$} \\
\hline & \multirow[t]{2}{*}{ Model } & \multicolumn{2}{|c|}{ Unstandardized Coefficients } & $\begin{array}{l}\text { Standardized } \\
\text { Coefficients }\end{array}$ & \multirow[t]{2}{*}{$\mathrm{t}$} & \multirow[t]{2}{*}{ Sig. } \\
\hline & & $\mathrm{B}$ & Std. Error & Beta & & \\
\hline \multirow[t]{4}{*}{1} & (Constant) & 18.229 & 6.734 & & 2.707 & .008 \\
\hline & total_x1 & .474 & .155 & .327 & 3.059 & .003 \\
\hline & total_x2 & .041 & .231 & .015 & .175 & .861 \\
\hline & total_x3 & .176 & .085 & .221 & 2.065 & .042 \\
\hline
\end{tabular}

Berdasarkan tabel 4.17 di atas dapat dianalisis model persamaan sebagai berikut:

Keterangan:

$$
\mathrm{Y}=18.229+0,474+0,041+0,176+e
$$

$\mathrm{Y}=$ Kualitas laporan keuangan pemerintah daerah

$\mathrm{a}=$ Konstanta

$\mathrm{X}_{1} \quad=$ Kualitas sumber daya manusia

$\mathrm{X}_{2} \quad=$ Implementasi sistem informasi manajemen daerah

$\mathrm{X}_{3} \quad=$ Penerapan standar akuntansi pemerintah

$\mathrm{Y}=$ Standar error

\section{Hipotesis 1}

Penelitian ini dapat membuktikan kualitas sumber daya manusia (X1) berpengaruh signifikan positif terhadap kualitas laporan keuangan pemerintah daerah, dengan demikian hipotesis pertama (H1) diterima.

\section{Hipotesis 2}

Penelitian ini dapat membuktikan implementasi sistem informasi manajemen daerah (X2) berpengaruh signifikan positif terhadap kualitas laporan keuangan pemerintah daerah, dengan demikian hipotesis kedua (H2) ditolak.

\section{Hipotesis 3}

Penelitian ini dapat membuktikan penerapan standar akuntansi pemerintah (X3) berpengaruh signifikan positif terhadap kualitas laporan keuangan pemerintah daerah, dengan demikian hipotesis pertama $(\mathrm{H} 3)$ diterima.

\section{PEMBAHASAN}

Penelitiaan ini melihatkan bahwasanya variabel kuailitas sumber daya manusia, implementasi sistem informasi manajemen daerah, dan penperapan standar akuntansi pemerintah berpengaruh signifikan positif terhadap kualitas laporan keuangan pemerintah daerah, secara total adalah $21,6 \%$ sedangkan sisanya secara lebih besar dipengaruhi oleh faktor lain, sedangkan menurut Gruilford (1956) hasil yang berada didalam angka 20-40\% dinyatakan rendah.

\section{Pengaruh Kualitas Sumber Daya Manusia terhadap Laporan Keuangan Pemerintah Daerah}

Hasil analisis statistik dalam penelitian ini diteimukan bahwa hipoteosis pertama $(\mathrm{H} 1)$ diteriuma dan disimpulkan bahwasanya kualitas sumber daya manusia memiliki pengaruh 
terhadap kualitas laporan keuangan pemerintah daerah pada OPD Provinsi Sumatera Barat. Pengaruh variabel sedang terhadap kualitas laporan keuangan pemerintah daerah, hal ini diduga karena sebagian pegawai pada OPD Provinsi Sumatera Barat masih kurang kompeten di bidang akuntansi dalam menyusun laporan keuangan, sebaiknya pemerintah diharapkan untuk melakukan evaluasi bagi penjabat yang tidak sesuai dengan kemampuan atas jabatan yang dipegangnya saat ini dan juga melakukan pendidikan diklat agar pemahaman untuk menyusun laporan keuangan semakin baik untuk kedepanya.

Kualitas laporan dikatakan meningkat apabila laporan tersebut dapat didukung oleh aparatur pemerintaanh yang memahami bagaiaman akuntansi pemerintah itu sendiri. Struktiur Organisasi Perangkat Daerah merupakan entitas akuntansi berkewajiban melakukan pencacata atas transaksi pendapatan, asset dan selain kas, oleh karena itu setiap bagian sutu dalam pemrintahan harus diisi oleh sumber daya mausia yang memliliki kometensi dalam mmahami akuntansi dan ilmu-ilmu keuangan dan memiliki informasi yang berkualitas (Wahyuno, 2004).

Sumber daya manusia faktor utama dan penggerak roda organisasi yang dimana bertuujuan agar laporan terbuat dengan bik dan benar dan juga merupakan elemen organisasi yang sangat pentingbnya. sumber daya manusia ini harus dikelola sebaik mukngkin agar dapat memberikan hubungan yang baik dalam pencapaian tujuan organisasi. Apablila dalam organiasi setiap individu bekerja dengan baik, dan memberikan kontribusi yang terbaik mereka terhadap organisasi, makaka kinerja organiasi secara keseluruhan akan baaik (Mahmudi, 2007). Penelitian ini sejalan dengan (Abidin \& Afifudin, 2018), (Adhi \& Suhardjo, 2013), (Kiranayanti \& Erawati, 2016), (Gumelar, 2017) dan (Ulfiati, 2017).

\section{Pengaruh Implementasi Sistem Informasi Manajemen Daerah terhadap Laporan Keuangan Pemerintah Daerah}

Hasil analisis statistik dalam penelitian ini ditemukan bahwa hipotesis kedua (H2) ditolak dan disimpulkan bahwa impleentasi sistem informasi maajemen daerh tidak berpengaruh terhadap bagaimana kualitas laporan keuangan pemerintah pada OPD Provinsi Sumatera Barat. Pengaruh variabel sangat rendah terhadap kualitas laporan keuangan pemerintah daerah, diduga karena kurangnya kemampuan pegawai dalam mengelola sistem informasi, hal tersebut tentunya akan mempengaruhi kualitas laporan keuangan pemmerintah daerah yang akan dihasilkan, seharuisnya pemerintah memberikan pembiinaan kepada pegawai agar dapat meningkatkan pemahaman dalam menggunakan simda dan mempeirbaiki sistem dokumen data.

Peraturan Pemerintah Nomor 56 Tahun 2005 tentang sistem informasi manajemen daerah, pemerintah daerah wajib dan memanfaatkan kemajuan teknologisi informasi didalami meningkatkan kemampuan dan dapat menglola keuangan dan meniingkatkan kinerja dan menghasilkan laporan keuakngan pemerintah daerah yang berkualitas. Penelitian ini sejalan dengan penelitian yang dilakukan oleh (Azzindani \& Pituringsih, 2019) tidak sejalan dengan (Abidin \& Afifudin, 2018).

\section{Pengaruh Standar Akuntansi Pemerintah terhadap Laporan Keuangan Pemerintah Daerah}

Hasil analisis statistik dalam penelitian ini ditemukan bahwa hipotesis ketiga (H3) diterima dan disimpulkan bahwa peneraipan standar akuntansi pemerintah berpengaruh positif terhadap kualitas lapokran keuangan pemerinitah pada OPD Provinsi Sumatera Barat. Hasil variabel sangat rendah terhadap kualitas laporan keuangan pemerintah daerah, diduga karena pegawai hanya menjalankan tugas dan tidak mengerti dengan standar, sebaiknya pegawai 
diberikan pemahaman terkait dengan standar akuntansi pemerintah karena standar tersebut merupakan acuan yang paling penting digunakan oleh pegawai dalam menyusun laporan keuangan sehingga menghasilkan suatu laporan keuangan yang berkualitas.

Penerapan Standar Akuntansi Pemerintah dapat memberikan pengaruh terhadap kualitas laporan keuangan pemerintah sebagai pertanggungjawaban keuangan pemerintah, yang mengharapkaan akan mengha;silkan sebuah laporan dipertanggungjawaban yang bermut. Sejalan dengan penelitian Nordiawan (2006) dalam Permana (2011) standar akuntansi pemerintah akan berdampak pada peningkatan kualitas laporan keuangan pemerintah pusat dan daerah. Penelitian ini sejalan dengan (Adhi \& Suhardjo, 2013), (Gumelar, 2017) dan (Ulfiati, 2017).

\section{KESIMPULAN DAN SARAN \\ Kesimpulan}

Hasil penelitian dan pengujian hipotesis yang telah dilakukan maka hasil penelitian ini dapat disimpulkan sebagai berikut :

1) Hipotesis pertama (H1) diterima dan disimpulkan bahwa kualitas sumber daya manusia memiliki pengaruh terhadap kualitas laporan keuangan pemerintah daerah pada OPD Provinsi Sumatera Barat. Pengaruh variabel sedang terhadap kualitas laporan keuangan pemerintah daerah, hal ini diduga karena sebagian pegawai pada OPD Provinsi Sumatera Barat masih kurang kompeten di bidang akuntansi dalam menyusun laporan keuangan.

2) Hipotesis kedua (H2) ditolak dan disimpulkan bahwa implementasi sistem informasi manajemen daerah tidak berpengaruh terhadap kualitas laporan keuangan pemerintah pada OPD Provinsi Sumatera Barat. Pengaruh variabel sangat rendah terhadap kualitas laporan keuangan pemerintah daerah, diduga karena kurangnya kemampuan pegawai dalam mengelola sistem informasi, hal tersebut tentunya akan mempengaruhi kualitas laporan keuangan pemerintah daerah yang akan dihasilkan.

3) Hipotesis ketiga (H3) diterima dan disimpulkan bahwa penerapan standar akuntansi pemerintah berpengaruh positif terhadap kualitas laporan keuangan pemerintah pada OPD Provinsi Sumatera Barat. Hasil variabel sangat rendah terhadap kualitas laporan keuangan pemerintah daerah, diduga karena pegawai hanya menjalankan tugas dan tidak mengerti dengan standar.

\section{Saran}

Berdasarkan kesimpulan diatas dapat diberikan saran sebagai berikut

1) Pemerintah diharapkan untuk melakukan evaluasi bagi penjabat yang tidak sesuai dengan kemampuan atas jabatan yang dipegangnya saat ini dan juga melakukan pendidikan diklat agar pemahaman untuk menyusun laporan keuangan semakin baik untuk kedepanya.

2) Pemerintah memberikan pembinaan kepada pegawai agar dapat meningkatkan pemahaman dalam menggunakan simda dan memperbaiki sistem dokumen data.

3) Pegawai harus memahami standar akuntansi pemerintah agar menghasilkan suatu laporan keuangan yang berkualitas.

4) Peneliti selanjutnya disarankan dapat memperoleh data melalui sumber lain seperti wawancara dari beberapa responden, sehingga dapat menggambarkan keadaan yang sebenarnya dan menghindari pengisian kuesioner yang kurang tepat. 


\section{DAFTAR PUSTAKA}

Agustin, Henri; Arza, Fefri Indra. (2019). Potrait of Accountability and Transparency in Local Budget Management by the Regional Government in West Sumatera Province, Indonesia: An Anomaly in Digital Era. $4^{\text {th }}$ Padang International Conference on Education, Economics, Business and Accounting (PICEEBA-2 2019). Padang. 154-166.

Abidin, Khoirul. M, Affifudin dan Junaidi. (2018). Pengaruh Implementasi Sistem IManajemen Daerah (SIMDA), Kualitas Sumber Daya Manusia Dan Penerapan Standar Akuntansi Terhadap Kualitas Laporan Keuangan Pemerintah Daerah Kota Malang. E-JRA..07(10).

Agustin, Henri. (2014). Publikasi Dokumen Pengelolaan Anggaran pada Website Pemkab/Pemkot di Propinsi Sumatera Barat. Seminar Nasional Aplikasi Teknologi Informasi (SNATI). Yogyakarta.

Adhi, Kartika. D dan Suhardjo Y. (2013). Pengaruh Penerapan Standar Akuntansi Pemerintahan Dan Kualitas Aparatur Pemerintah Daerah Terhadap Kualitas Laporan Keuangan (Studi Kasus Pada Pemerintah Kota Tual). Jurnal Stie Semarang, 5 (3).

Alfian, Mohammad. (2015). Faktor faktor yang mempenagruhi Implementasi SIMDA dan kualitas laporan keuangan SKPD. Jurnal Akuntansi dan Investasi, 16(1).

Alfiani, Nur dan Atwal Arifin,. 2017. Pengaruh Impelementasi Sistem Informasi Manajemen Keuangan Daerah (SIMDA), Kualitas Sumber Daya Manusia (SDM), dan Dukungan Manajemen Puncak terhadap Kualitas Laporan Keuangan Daerah (Penelitian Pada Pemerintah Kabupaten Tegal). Tesis. Universitas Muhammdiyah Surakarta.

Amsari, Feri. "Status WTP Sumbar Patut dicurigai". https://www.harianhaluan.com, diakses tanggal 17 Mei 2019.

Anton (2010). Menuju Teori Stewardship Manajemen. Majalah Ilmiah Informatika. Jurnal Akuntansi, 1(2).

Azhar, Susanto. (2007). Sistem Informasi Akuntansi. Jakarta: T. Lingga Jaya.

Azzindani, R., \& Pituringsih, E. (2019). Pengaruh Implementasi Simda, Kinerja Aparatur Pemerintah Daerah Dan Penerapan Sap Terhadap Kualitas Lkpd Lombok Tengah. EJurnal Akuntansi Universitas Udayana, 27, 418-445.

Bastian, I. (2010). Audit Sektor Publik. Jakarta: Salemba Empat.

Defitri, S. Y. (2016). Pengaruh Pemahaman Akuntansi Dan Pemanfaatan TeknologiInformasi Terhadap Kualitas Laporan Keuangan Pemerintah Daerah. Jurnal akuntansi. Vol.12.No.1.

Dessler, G. (2003). Manajemen Sumber Daya Manusia, Edisi Kedelapan. Jakarta: Pretince Hall.

\section{INDEKS.}

2006. Manajemen Sumber daya Manusia, Edisi Kesepuluh. Jakarta: PT

Dewi. (2015). Pengaruh Kompetensi dan Penerapan Sistem Akuntansi Keuangan Daerah terhadap Kualitas Keuangan Daerah pada Satuan Perangkat Daerah (SKPD) Kabupaten Lawang Sumatera Selatan. Jurnal Ekonomi, Manajemen dan Akuntansi.

Emilda, I. 2014. Pengaruh Kompetensi Sumber Daya Manusia dan Penerapan Sistem Akuntansi Keuangan Daerah terhadap Kualitas Laporan Keuangan Daerah (Studi Empiris pada SKPD Kabupten Lima Puluh Kota. Skripsi. Universitas Negeri Padang.

Fikri, dkk. (2016). Pengaruh Penerapan Standar Akuntansi Pemerintahan, Kompetensi Aparatur dan peran audit internal terhadap kualitas informasi laporan keuangan. Jurnal Akuntansi, 12(1). 
Galuh, D. 2012. Pengaruh Kapasitas Sumber Daya Manusia, Pemanfaatan Tekonologi Informasi dan Pengawasan Keuangan Daerah Terhadap Infromasi Pelaporan Keuangan Daerah dengan Sistem Pengendalian Internal sebagai variabel Moderating. Skripsi Fakultas Ekonomi Universitas Negeri Padang.

Grande, E.U., R. P. Estébanez dan C. M. Colomina. (2011). Dampak Sistem Informasi Akuntansi (SIA) pada Ukuran Kinerja: Bukti Empiris di UKM Spanyol. The International Journal of Digital Accounting Research.

Gumelar, A. 2017. Pengaruh Kualitas Sumber Daya Manusia, Penerapan Standar Akuntansi Pemerintah dan Pengendalian Intern terhadap Kualitas Laporan Keuangan Pemerintah (Studi pada SKPD di Kabupaten Kerinci). Skripsi. Universitas Negeri Padang.

Halmawati \& Nova, Wati Sri. (2014). Pengaruh Pemahaman Akuntansi, Komitmen Karyawan dan Peran Internal Audit Terhadap Kualitas Laporan Keuangan Pemerintah Daerah (Studi Empiris pada Satuan Kerja Perangkat Daerah di Kabupaten Sijunjung). Jurnal WRA. 2(2), 455-474.

Hall, James A. (2007). Sistem Informasi Akuntansi. Edisi. 4. Jakarta: Salemba Empat.

Indriasari, D dan Nahartyo E. (2008). Pengaruh Kapasitas Sumber Daya Manusia, Pemenfaatan Teknologi Informasi dan Pengendalian Intern Akuntansi Terhadap Nilai Informasi Pelaporan Keuangan Pemerintah Daerah. Simposium Nasional Akuntansi, XXI, Pontianak.

Khirunnisa, E. 2016. Pengaruh Efektifitas Penggunaan, Kepercayaan, Pemanfaatan, dan Keahlian pada Teknologi Sistem Informasi Manajemen Daerah(SIMDA) Terhadap Kinerja Individu pegawai (Studi Empiris pada Satuan Kerja Perangkat Daerah Kota Surakarta). Skripsi. Universitas Muhammadiyah Surakarta.

Kiranayanti, dkk. 2016. Pengaruh Sumber Daya Manusia, Sistem Pengendalian Intern, Pemahaman Basis Akrual Terhadap Kualitas Laporan Keuangan Daerah. E-Jurnal Akuntansi Universitas Udayana Vol.16. No.2.

Kusumah, A. A. (2012). Pengaruh Penerapan Standar Akuntansi Pemerintahan Terhadap Kualitas Laporan Keuangan (Survei pada SKPD/OPD Pemerintah Kota Tasikmalaya). Jurnal Akuntansi, 12(2).

Mahmudi. 2007. Manajemen Sektor Publik. Yogyakarta: UPP STIM YKPN. 2010. Analisa Laporan Keuangan Pemerintah Daerah Edisi Kedua. UPPＳ STIM

YPKN. Yogyakarta.

Mardiasmo, (2002). Akuntansi Sektor Publik Edisi Pertama. Yogyakarta: Penerbit Andi. (2009). Akuntansi Sektor Publik Edisi Keempat. Yogyakarta: Penerbit Andi.

Mohamad, H, Laode, R. A. S. U. L. I \& Machmud, R. (2014). Pengaruh Kualitas Sumber Daya Manusia Dan Penerapan Teknologi Sistem Informasi Manajemen Keuangan Daerah (SIMDA) Terhadap Kualitas Laporan Keuangan Pemerintah Daerah (Studi Kasus Pemerintah Daerah Kota Gorontalo). KIM Fakultas Ekonomi \& Bisnis, 2(1).

Novia, Siswita; Arza, Fefri Indra; Agustin, Henri. (2015). Studi Kebutuhan Informasi Pengguna Laporan Keuangan Pemerintah Kota Padang (Studi Empiris pada DPRD dan SKPD Kota Padang). Jurnal WRA, 3(1), 529-548.

Nordiwan, D. (2008). Akuntansi Pemerintah. Jakarta: Salemba Empat.

Nugraheni, P dan Subaweh, I. (2008). Pengaruh Penerapan Akuntansi Pemerintah terhadap kualitas laporan keuangan. Jurnal Ekonomi Bisnis, 13(1). 
Ole, H. R. (2014). Analisis Implementasi Sistem Informasi Manajemen Daerah (SIMDA) Terhadap Kualitas Laporan Keuangan SKPD (Studi Kasus Pada Dinas (PPKAD) Kabupaten Minahasa Tenggara). E-Joernal, 3(2).

Peraturan Pemerintah No. 8 Tahun 2006 Tentang Pelaporan Keuangan dan Kinerja Instansi Pemerintah.

Peraturan Pemerintah No. 24 Tahun 2005 Tentang Standar Akuntansi Pemerintah (SAP).

Peraturan Pemerintah No. 71 Tahun 2010 Tentang Standar Akuntansi Pemerintah Indonesia.

Peraturan Pemerintah No. 56 Tahun 2005 tentang Sistem Informasi Keuangan Daerah.

Peraturan Pemerintah No. 24 tahun 2005 Karakteristik kualitatif laporan keuangan.

Permana, I. 2011. Pengaruh Penerapan Standar Akuntansi Pemerintahan terhadap Kualitas Laporan Keuangan Pemerintah Daerah Dan Implikasinya Pada Akuntabilitas Survei Pada Dinas Kota Bandung. Skripsi. Universitas Komputer Indonesia. Bandung.

Poerwadarminta. 2006. Kamus Umum Bahasa Indonesia. Jakarta: Balai Bahasa.

Rivai, V. (2005). Kepemimpinan dan Perilaku Organisasi, PT. Raja Grafindo Persada: Jakarta.

Sanjaya, A. (2017). Pengaruh Penerapan Standar Akuntansi Pemerintahan, Sistem Pengendalian Intern, Sistem Akuntansi Keuangan Daerah, Dan Sumber Daya Manusia Terhadap Kualitas Laporan Keuangan Pemerintah Daerah Dengan Komitmen Organisasi Sebagai Pemoderasi (Studi Pada SKPD Kabupaten Kampar). Jurnal Akuntansi, 4(1).

Sako, U dan Felmi D. L. (2018). Pengaruh Penerapan Standar Akuntansi Pemerintahan Terhadap Kualitas Penyajian Laporan Keuangan Pada Pemerintah Kabupaten. Gorontalo Jurnal Akuntansi, 2(1)

Salehi, M, V. Rostami dan Mogadam. A. (2010). Kegunaan Sistem Informasi Akuntansi dalam Ekonomi Berkembang: Bukti Empiris Iran. Jurnal Internasional Ekonomi dan Keuangan. Jurnal Akuntansi. Vol.2.No.2.

Sanusi, A. (2011). Metodologi Penelitian Bisnis. Penerbit Salemba Empat: Jakarta.

Sedarmayanti, (2004). Pengembangan Kepribadian Pegawai. Penerbit Mandar Maju, Bandung.

Simanjuntak, P. J. 2005. Manajemen dan Evaluasi Kerja. Lembaga. Penerbit: FEUI, Jakarta.

Soemarso. (2010). Akuntansi Suatu Pengantar. Edisi 5. Cetakan keenam. Jakarta: Rineka Cipta.

Soewardjono. (2005). Teori Akuntansi: Perekayasaan Pelaporan Keuangan (Edisi III). Yogyakarta: BPFE.

Susilawati, R. (2014). Standar Akuntansi Pemerintahan dan Sistem Pengendalian Intern Sebagai Anteseden Kualitas Laporan Keuangan Pemerintah Daerah. Jurnal Akuntansi,1(3).

Sugiyono. (2010). Metode Penelitian Administrasi. Bandung: Alfabeta.

Sugiyono. (2011). Metode Penelitian Administrasi. Bandung: Alfabeta.

Sugiyono. (2013). Metode Penelitian Pendidikan Pendekatan Kuantitatif, Kualitatif dan $R \& D$.

Bandung: Alfabeta.

Umar, H. (2005). Metode Penelitian. Salemba Empat. Jakarta

Undang-Undang No. 17 tahun 2003 Tentang Keuangan Negara.

Undang-Undang No. 1 Tahun 2004 tentang Perbendaharaan Negara.

Ulfiati, Nur. 2017. Pengaruh Implementasi Sistem Informasi Manajemen Daerah, Kualitas Sumber Daya Manusia Dan Penerapan Standar Akuntansi Pemerintah Terhadap Kualitas Laporan Keuangan Daerah. Skripsi. Universitas Muhamadiyah Surakarta. 
Wahida, N. 2015. Pengaruh Penyajian Laporan Keuangan Daerah dan Aksesibilitas Laporan Keuangan Daerah Terhadap Akuntabilitas Pengelolaan Keuangan

Daerah

Kabupaten Konawe Utara. Skripsi. Makassar. Universitas Hasanuddin Makassar.

Wahyuni, A. 2011. Pengaruh Penggunaan TI, Keahlian Pemekai dan Keterlibatan Pamakai terhadap Efektifitas Penerapan SIA. Skripsi. Fakultas Ekonomi UniversitasNegeri Padang.

Wati, K.D Dkk. (2014). Pengaruh Kompetensi SDM, Penerapan SAP, dan Sistem Akuntansi Keuangan Daerah terhadap Kualitas laporan keuangan daerah. E-Joernal. 2(1).

Waskito, 2014. Pengaruh Penerapan Aplikasi Sistem Informasi Manajemen Daerah (SIMDA) Terhadap Kualitas Laporan Keuangan Pemerintah Daerah Kabupaten Rembang.

Wursanto. 2005. Dasar-Dasar Ilmu Organisasi. Yogyakarta: Andi.

Zeyn, E. (2011). Pengaruh Good Governance dan Standar Akuntansi Pemerintah terhadap Akuntabilitas keuangan dengan komitmen Organisasi sebagai Pemoderasi. Jurnal Akuntansi Universitas Pasundan. 